\title{
Lack of liberal education at tertiary level: A study on Newman's The Idea of a University and Hirani's 3 Idiots
}

\author{
Md. Morshedul Alam \\ Department of English Language and Literature (ELL) \\ International Islamic University Chittagong (IIUC), Bangladesh \\ Golshan Ara Akter and Nahida Afrin \\ $M A$ Student, ELL \\ International Islamic University Chittagong (IIUC), Bangladesh
}

\begin{abstract}
This paper deals with the process of university education system, how students will enrich the knowledge and skills, develop the power of reasoning and judgments and promote the creativity. It also advocates a holistic approach in liberal education system that preserves a harmonious relationship among the real cultivation of mind, intellectual excellence and freedom of thought. Newman's The Idea of a University and Hirani's3 Idiots have been studied in line with liberal education of university which gives the enlargement of knowledge that pertains to the universal appeal of education system. In this study, some barriers, such as, market value, guardian's choice and mental depression are addressed as the potential threats for liberal education. Therefore, this research is an attempt to make a comparative study of Newman's The Idea of a University and Hirani's 3 Idiots as illustrating the liberal education of university and generating an image of liberal education in present society.
\end{abstract}

Keywords Creativity, Education system, Enlargement of knowledge, Liberal education, Tertiary level

Paper type Research paper

\section{Introduction}

John Henry Newman (1801-1890), an eminent and controversial figure in the history of England in the 19th century, was not only an Anglican poet, but also a Catholic cardinal and a theologian. He had a good number of literary works to his credit: Tracts for the Times (1833-1841), Apologia Pro Vita Sua (1865-1866), The Dream of Gerontius (1866) The Grammar of Assent (1870) and The Idea of a University (1873). "Lead kindly Light" and "Praise to the Holiest in the Height" are his popular hymns. On the other hand, Rajkumar Hirani (1962- present) is a versatile genius. He is an Indian film director, script writer, editor and producer. His worldwide

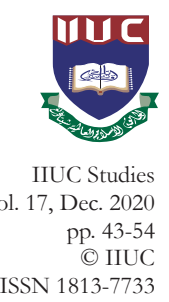




\section{IIUC Studies, 17}

name and fame is for directing Hindi films, such as Munna Bhai M.B.B.S (2003), Lage Rabo Munnabhai (2006), 3 Idiots (2009) and PK (2014). He has received several awards for his works: 51th National Film Awards (2004), Bollywood Movie Awards (2006) CNN-IBN Indian of the year (2006), Star Screen Awards (2010),16th IIFA Awards (2010) etc.

His movies are a moving account of the contemporary educational system, social and religious crises that exist in the whole world. On the contrary, The Idea of a University of John Henry Newman manifests 'Liberal education' as the principal purpose of a university. It is considered as a classic work on university education. Like Newman's The Idea of a University, Rajkumar Hirani also glorifies the university education system in his movie 3 Idiots. He is inspired to produce this movie by Chetan Bhagat's novel Five Point Someone. This paper is an attempt to show the similarities between The Idea of a University of Cardinal Newman and Hirani's3 Idiots movie about the system of university education.

\section{Education}

Education is globally recognized process of formal learning or the acquisition of knowledge and skills. It also enhances students' wisdom, values, beliefs, habits and above all the enlightenment of thoughts. According to Mandela (2003),

"Education is the most powerful weapon which you can use to change the world."

According to Kennedy (1956),

"The goal of education is the advancement of knowledge and the dissemination of truth."

According to Aristotle (n.d.),

"Education is the creation of a sound mind in a sound body."

To Dewey (1994),

"Education is the development of all those capacities in the individual which enable him to control his environment and fulfill his possibility"

According to Dictionary of Education,

1. Education assembles the process by which a person exhibits qualities, thoughts, and diverse forms of attitudes of true changes and values in the society.

2. "The social process by which people are subjected to the influence of a selected and controlled environment so that they may attain social competence and optimum individual development." (Zahara, 1992) 


\section{University education}

University Education is the highest seat of institutional education which is a place of research, a light of world to provide knowledge and increase moral value of mind. University education is known as tertiary level of education where knowledge is not only provided but also created. In both Bangladesh and India, the picture of tertiary education is frustrating. Career oriented higher education creates a medieval mind set where the scope of liberal education at university level is quite tough. "This I conceive to be the advantage of a seat of universal learning, considered as a place of education." (Newman, 1873)

Newman focuses on the purpose of university education. According to Newman, a university provides training to the learners to be the ordinary meaning; its objective is to raise the intellectual tone and consciousness of society. University education is a kind of teaching which gives a man, a distinct awareness of his own judgment and opinions, a truth on improving them, an oratory in expressing them and a power in guiding them.

\section{Liberal education}

In tertiary level pedagogy, liberal education is a concept or philosophy of teaching that incorporates individual with wide knowledge and intellect. It also aims at providing skills and a stronger intuition of values along with ethics and morality, civic knowledge which is distinguished by significant issues and more a way of reading than a particular course of study. "Liberal education and liberal pursuits are exercises of mind, of reason, of reflection" (Newman, 1873).

Liberal education is "well-rounded". In history, the notion of liberal education was promoted by Plato, Aristotle, Augustine, Aquinas and many other great idealists in the past. John Henry Newman developed the concept of liberal education in The Idea of University following the great thinkers of the past. For Newman, the main principle of liberal education is to develop all things in us so that we can become distinctively humane. (www.sites.goole.com/a/nd.e)

In 3 Idiots movie, when teachers become angry and get out Rancho from one classroom, he goes and sits in another classroom. He used to say that

RANCHO: Charotoropghanbarta...

Jahoche mile ... lov it! (Hirani, 2009)

[RANCHO: Knowledge increases everywhere...

Wherever you go, get ...gain it! (Hirani, 2009)]

Newman also says, man will develop expertise in various sections of knowledge by training and he is able to achieve a sense of universal 
knowledge and wisdom through liberal education. This knowledge enables us to see all branches of knowledge and intellect not only as forming one but also a coherent whole.

\section{Technical education}

The technical education refers to the both academic and vocational preparation of learners for job which involves in acquiring practical knowledge and skills related with applied science and modern technology. Technical education has no purpose in acquiring wisdom and gathering knowledge. Its main purpose is to get a good job. It is also called professional education. Newman says, "Professional education which commonly engrosses the title of useful". (Newman, 1873)

\section{Comparison between the Idea of a University and 3 Idiots Enriching the knowledge}

In Bangladesh and India, liberal education at tertiary level is quite rare as syllabus and materials have been designed in such a way that education becomes joyless rather examination and certificate oriented. Here, learners at tertiary level are much more job seekers than knowledge seekers. Due to acute unemployment and poor socio-economic condition, students are very much career oriented instead of achieving knowledge and widening outlook. 3 Idiots by Raj Kumar Hirani (2009) reflects the true picture of education system in South Asian context particularly in India. In both Bangladesh and India, almost at every level, students are much under pressures such as high ambition, familial and social expectation and wrong mind set of success.

However, in The Idea of University, Newman emphasizes the liberal education to enrich the power of knowledge. Liberal education is that type of education which produces nothing profitable but is valuable in a sense that it maintains its ground for ages due to its self- sufficiency and independent value. "Those are useful that bear fruits and those are liberal that tend to enjoyment." (Newman, 1873)

\section{Purify the human soul by knowledge}

Newman's concept of our universities that he emphasizes is a collision of thought with thought and intellect with intellect to find out the truth. We think, the way of solving problem is power where knowledge bears little meaning and leads to the narrowness of mind. He again says in the lack of the system of liberal education, a learner cannot discursively mature and he will be "slave or children", despite having some upper degrees. "A narrow 
mind is thought to be that which contains little knowledge; and an enlarge mind, that which holds a great deal; and what seems to put the matter beyond dispute is the fact of the great number of studies which are pursued in a university, by its very profession". (Newman, 1873)

On the other hand, in 3 Idiots movie, we also see that Prof. Virus sir and Chatur's mind are not pure. Prof. Virus has never inspired Farhan and Raju. He has insulted them. Besides, in the exam time, Chatur disturbs other friends and he gives pornography book to them secretly so that they cannot concentrate their study. At the end of the movie, Chatur has insulted Rancho because he is a school master.

CHATUR: Namaste masterji, tom kothepochega? Tom howga school master, eh? A for apple ...B for ball.... (Hirani, 2009) [CHATUR: Namaste masterji, where have you reached? You have become a teacher in the village, eh? A for apple....B for ball.... (Hirani, 2009)]

\section{Personal preference versus guardian imposition in education Students learn their own way}

Newman emphasizes on personal preference of students in their learning system and also says that "Each man is to be trusted in his own special art". (Newman, 1873). A researcher, Saeful in his article stated, "Education is the process of development of potential, capabilities and human capacity which is easily influenced by habit, then refined by the moral habits and supported by the tool which arranged in such a way so that education can be used to help others or himself in achieving the goals". (2012)

\section{Education has no academic purpose}

Seaful states in his research "National standard of education has a purpose to guarantee for quality of national education in framework to create intelligent manpower of nation and to form the character and civilization of the nation prestige." (Saeful, 2012) Newman has given the value of liberal education which makes a student knowledgeable and increases his overall understanding and widens knowledge. He will not keep himself engage in academic rules for gathering only bookish knowledge.

"Some great men argue as if everything as well as every person, had its price; and that where there has been a great outlay, they have a right to expect a return in kind". (Newman, 1873)

They address this as making teaching and process "useful" and "utility" that turns their motto. With a principal guiding of this characteristic, they go on to ask for the expenditure of a university.... (Newman, 1873) 


\section{Enlargement of knowledge}

Enlargement of knowledge is connected with one another. A famous researcher, Kar (2011) stated in his article "Newman's The Idea of a University and its relevance for the 21th Century": The enlargement of idea attains its maximum point in "a truly great intellect" which "possesses the knowledge, not only of things, but also of their mutual and true relations."

True enlargement of mind is the ability of seeing many issues at once as one whole of mentioning them in turn to their true position. In the general process of understanding, their respective moral and ethical values, ascertain their mutual reliance occupying of their true enlightenment. The mind never examines any part of the content of knowledge without reflection or without the affinities which emerge from this recollection. It generates all in some forms which lead to everything else; it would impart the embodiment of the whole to each individual portion, the whole becomes an imagination like a psyche, extending and piercing its components, and giving them one specific meaning.

Newman emphasizes both useful and good education which did not create any mental depression. "Though the useful is not always good, the good is always useful”. (Newman, 1873)

\section{Guardian imposition on education}

In 3 Idiots movie, we see that Guardians impose on their own choice in shaping careers or aims in life as top down process to their children and do not evaluate their children's preference. Even before the birth of a child, guardians take decision; what they would be in future. Few minute later of Farhan's birth, his father decided his son's goal of life.

FARHAN'S FATHER: Mere beta engineer bone ga. (Hirani, 2009)

[FARHAN'S FATHER: My son will become an engineer. (Hirani, 2009)]

PRIYA: Papa kaha, larka howatoh engineer, lurki

Howa toh doctor bannega. (Hirani, 2009)

[PRIYA: If it's a boy, it's an engineer and if it's a girl, it's a doctor.

(Hirani, 2009)]

In this movie, education is considered valuable for academic purpose. It also means the all-out development of both body and mind.

Prof. VIRUS: Na pass ho genana company une job bejenggi! (Hirani, 2009)

[Prof. VIRUS: Neither will they pass nor any company will give jobs to them! (Hirani, 2009)] 
In this movie, Rancho wants the excellence of knowledge and he never desires for degree. At last, Rancho gives his degree to real Rancho and he becomes a great scientist as name of Phunsuk Wangdu. Real Rancho's father says to Phunsuk Wangdu's childhood:

RANCHO'S FATHER: Uche knowledge chaiye, mere seref degree. (Hirani, 2009)

[RANCHO'S FATHER: He wants education....and me...just...degree. (Hirani, 2009)]

\section{Mental depression}

Here, the guardians and teachers emphasize useful education or professional learning for materialistic and worldly success which creates great mental depression. Prof. Virus sir, being a graduate, creates mental pressure to his son's choice and his students' mind. The creativity of students is not inspired and promoted rather he insults them. When Joy lobo cannot submit his project, he is insulted by Prof. Virus sir. As a result, he has lost his inspiration, and he has committed suicide because of his depression.

JOY LOBO: Sir, I am in very close, ubektorfhadekhiliye je

And thorasa extension dije. (Hirani, 2009)

JOY LOBO: at least take a look at this once, sir

Please give me some extension. (Hirani, 2009)]

Prof. VIRUS: Me tume sympathy de sakta o extension nehi. (Hirani, 2009)

[Prof. VIRUS: I can only give you compassion not extension. (Hirani, 2009)]

\section{Intellectual excellence}

Newman says the business of a university is to seek truth through the application of intellect and a student comes to university with an aim to develop his intellectual excellence or power. The substance of Newman's concept of university is therefore an institution where men are trained to enrich thinking faculty. The practical utility of the university was pedagogic, but to acquire wisdom was only a cause to its substantive end, which was "Thought or reason exercised upon knowledge, or what may be called philosophy" (Newman, 1873). To gain this it is essential that entire sciences (by which he intended every branch of knowledge) should be learnt on the ground of equality, as they accomplish, correct balance in one other. It is built in an authentic and distinct atmosphere of thoughts which the learners also breathe; through their own case they only pursue a few branches of sciences out of the multitude.

In the Nicomachean Ethics, Aristotle argues that intellectual excellence is an 
acquired possession. We are born with the capacity for this possession. On the other hand, intellectual virtue or excellence can only be instilled, actualized and acquired through the proper energetic exercise of that capacity that is through training and repeated practice. The goal of education is not to teach what virtue is, but to mold students into virtuous individuals. If people are virtuous democratic government thrives and the best interests of the nation are served. (Aristotle, n. d)

Through the system of liberal education, a student can nurture the quality of tolerance, civility, and creativity needed in the active citizens of democracy and removes the root of corruption. In 3 Idiots movie, we see that Rancho shows his intellectual excellence by establishing a school where the children will learn their own way and make use of application, analysis, synthesis and evaluation in enabling them to formulate creative solutions to problems.

\section{Newman's viewpoint}

Newman's concept of university education is focused on mainly liberal education. He thinks that the principal purpose of university is to seek truth through the application of knowledge and intellect. The exposition of diverse branches of study originates students who will be knowledgeable, balanced, and tranquil. Newman says that these are the significant views for a success in generating intellectuals. He narrates knowledge as "The indispensable condition of expansion of mind, and the instrument of attaining to it". (Newman, 1873) The achievement of this type of wisdom and intellect will lead to the "Enlargement of mind" in which learners are completely associated with ideas and concept.

\section{Director Rajkumar Hirani's viewpoint}

Hirani shows the necessity of liberal education which makes a student knowledgeable and they can change the society and traditional education system. Hirani in his movie 3 Idiots tries to address the issue that parents must consider and realize the expectations and the quality of their children so that they remain aloof from taking wrong steps in teaching and should not put on their wish.

RANCHO: Bachcha kabil bano, kabil...

kamyabi toh saali jhak maarke peeche bhagegi. (Hirani, 2009)

[RANCHO: Pursue excellence and success will follow. (Hirani, 2009)] Hirani also shows the unusual dominating role of teachers who are severely strict and formal in institutions and they cannot give any inspiration and 
motivation about liberal education. Prof. Virus sir is a kind of teacher who creates mental pressure which damages students' creativity.

RANCHO: Asse pore upko knowledge bari? nahi, seref pressure bari, a ye collge pressure cooker nahi he, sabukkidorche circus kaser bi kusal bi be nashikajata, sar bi well trained kotiheiwell educated nahi. (Hirani, 2009)

[RANCHO: Will you develop your knowledge and wisdom? No, only pressure will rise and it is a college, not a pressure cooker, even the lion in the circus also knows how to sit on the chair earing the whip held in his owner's hand but we call such a lion as well trained, not well educated. (Hirani, 2009)]

\section{Effect on society and realization of life}

Modern education system makes man ultra -materialistic because it lacks liberal education. Therefore, this system produces materialistic, money mongering, greedy and selfish generation instead of liberal mind and outlook. By instructing students, how to think rather than what to think, and how to learn rather than what to learn, a liberal education generates graduates who are capable enough to adjust and answer to the needs of economic and social environment. Bloom and Rosovsky (2003) has stated in their journal, "Why Developing Country should not Neglect Liberal Education":

Thomas Jefferson viewed; liberal education can create the standard placed by a society based on merit, in contrast to rank or riches at birth. Therefore, liberal education promotes cohesion not just within, but also among societies and countries. The studying of the major religions of the world can help students find the associations among them, at the same time the differences. To know a country's past and present ways of culture and behavior, studying language, literature, history, and religion may shed light in readers' mind. (Bloom \& Rosovsky, 2003)

At present in Bangladesh, university education system cannot reach the expected goal of liberal education. Students and teachers always think about the profession and they are encouraged to get involved in politics by the government and political parties. As a result, students only learn but they do not become knowledgeable. They are losing their hope and, day by day, unemployment problem is increasing and country is losing its enlightening and creative generation. In addition, this existing education system fails to create generation having widening outlook and developing critical thinking. Therefore, most of the educated youth are getting frustrated and unemployed. K. Tharindus says about the higher education of Bangladesh in 
his discussion "What is the basic problem of Higher Educational System of Bangladesh?"

1. The system emphasizes more on having good grades rather than learning. As a result, students are encouraged to do rote memorization rather than hands on learning.

2. Testing system is horrible. It doesn't test the skill of the student. It tests the memorization powers.

3. Teachers are more interested in maintaining their superiority rather than acting as mentors. So, they do not accept their deficiency and are harsh to students. Because of the system of education, teachers in lieu of developing friendly relationships with learners create fear and always hide their shortcoming by showing rudeness.

4. Students always search for shortcomings of teachers.

5. Most of the higher educational institutions are not involved in any kind of research because they either do not obtain any fund from the government for research, or the government does not involve them in any research activity.

6. Students either hate or scared of unfriendly teachers. Therefore, transmission of liberal education is severely halted.

\section{Conclusion}

The Idea of a University and 3 Idiots advocate for liberal education in university and show its great impact in both personal and social life. Newman appeals to incorporate liberal education to constitute a better and standard society and depicts the overall concept of education in his book. Now, our present life ruled by materialistic and selfish outlook markedly suffers from the lack of a spiritual and ethical view of life. In today's world, most probably, the root cause of the crisis and unrest lies in the spiritual barrenness and nihilistic view of life from which modern men suffer. The meaninglessness of life produces immoral and unethical viewpoint of education. By following the liberal education system, university students can develop analytical skills, practical knowledge, ethical judgment, humanism and social responsibility. Bacon also shows the benefit of education in such depiction "Studies serve for delight, for ornament and for ability." (Bacon, 1985) 


\section{References}

Aristotle. (n. d.). Curriculum and Method of Education. Greek. Speech.

Aristotle. (n. d.) Nicomachean Ethics. W. D. Ross, 1103a, (pp.14-16), 23-25.

Bacon, F. (1985). Of Studies. The Essays (Ed.). Harmondsworth: Penguin.

Bloom, D. E. \& Rosovsky, H. (2003). Why developing country school not neglect liberal education. Association of American Colleges and Universities, 89(1), 16-23.

Dewey, J. (1994). Suwarno, Speech.

Hirani, R. (2009). 3 Idiot., India: Film.

Kar, I. (2011). Newman's idea of a university and its relevance for the 21 st century. Australian eJournal of Theology, 18(1), 19-31.

Kennedy, F. J. (1956). Harvard University, USA, Speech.

Saeful, A. (2012). Education Values in the 3 idiots movie. Unpublished thesis: Tarbiyah Faculty. Satate Islamic Studies Institute (STAIN), Salatiga.

Mandela, N. (2003). Lighting your way to a better future: Launch of Mindset Network. Speech.

Newman, H. J. (1873). The Idea of a University. India: Prakash Book Depot.

Zahara, D. (1992). Penganter Pendidikan.

\section{Corresponding author}

Md. Morshedul Alam can be contacted at: morshedeng82@gmail.com 
54 IIUC Studies, 17 